\title{
The Influence of Think-Pair-Share (TPS) on Improving Students' Oral Communication Skills in EFL Classrooms
}

\author{
Ahmed Amin Awad Raba \\ College of Education and Teacher Training, An-Najah National University, Nablus, Palestine \\ Email:ahmedm@najah.edu, ahmedawad_amin@yahoo.com
}

How to cite this paper: Raba, A. A. A. (2017). The Influence of Think-Pair-Share (TPS) on Improving Students' Oral Communication Skills in EFL Classrooms. Creative Education, 8, 12-23. http://dx.doi.org/10.4236/ce.2017.81002

Received: November 10, 2016

Accepted: January 10, 2017

Published: January 13, 2017

Copyright $\odot 2017$ by author and Scientific Research Publishing Inc. This work is licensed under the Creative Commons Attribution International License (CC BY 4.0).

http://creativecommons.org/licenses/by/4.0/

\section{(c) (i) Open Access}

\begin{abstract}
This research aimed to investigate the influence of think-pair-share (TPS) on improving students' oral communication skills in EFL classrooms. For this purpose, the researcher interviewed the EFL teachers who taught "English for Workplace" at the ELC An-Najah National University and observed students' classroom interaction. After the analysis of the collected data of the study, it was obviously noticed that think-pair-share strategy plays a positive role in improving students' oral communicative skills, creating a cooperative learning environment and enhancing students' motivation to learn better. Furthermore, students enrolled in the faculties of applied sciences responded better than students enrolled the faculties of human sciences; similar responses were shown from students of higher academic level. In the light of these findings, the researcher recommended increasing the number of activities related to think-pair-in the English textbooks and in the teaching pedagogies for the sake of improving students' oral communication skills.
\end{abstract}

\section{Keywords}

Think-Pair-Share, Oral Communication Skills, FL Classrooms

\section{Introduction}

Speaking is an important part of everyone's life. It is the second productive language skill and an essential means of communication. It is a channel through which people interact, communicate, discuss and share their own ideas and perceptions about their surrounding environment. Moreover, they speak to explain how they feel about others. One of the most common problems students have is communicating through speaking in a foreign language. It is considered an obstacle that prevents them from expressing themselves in an appropriate and pro- 
fessional way (Chaney \& Burk, 1998).

Additionally, mastering speaking appropriately needs a great effort as it requires skillful integration of certain language aspects such as vocabulary, correct grammar, sentence structure and correct pronunciation. Thus, teaching oral communication appropriately has not yet been met, and one can find much to explore in this field. Because of the significant role of speaking, many researchers like Bailey (2005) and Goh (2007) have proposed methods to enhance speaking skills by means of syllabus design, teaching principles, types of tasks and materials, and speaking assessment. Promoting speaking confidence will be accomplished through appropriate selection of tasks along with the teaching pedagogies as highlighted by researchers such as Bailey, 2005; Nunan, 2006; Patil, 2008; Trent, 2009 and Zhang, 2009.

One effective technique that the researcher wants to emphasize in this research is the think-pair-share that was proposed by Lyman (1981). The researcher aimed to investigate the positive effects of implementing this strategy in EFL classrooms to improve communication and enhance speakers' motivation to learn better. The researcher presented both the advantages and disadvantages of think-pair-share strategy along with discussing its influence on the students' motivation toward communication in L2.

\section{Theoretical Background}

Think-pair-share is a cooperative learning technique that was first proposed by Lyman (1981). In fact, it is a three-step technique where students think about a given question or problem, given a limited time to think, organize their thoughts and formulate their ideas and answers to the given questions. Then, they move to the next step where they work in pairs and discuss their answers. This step according to Pressley 1992 gives students opportunity to think and provides them with a good chance to find out what they know and what they need to know. In the last step according to Millis, 2012, students share their ideas with the whole group. Of course, it differs from the traditional strategies such as lecturing because it allows a great deal of interaction where students can reflect on their own ideas in a very active manner.

Think-pair-strategy reinforces students' communication skills. Each student takes his chance to speak, discuss and participate which has many positive effects on the whole group where students feel more self-confident and more active in the class. Moreover, they learn to listen to each other point of view and to respect each other ideas and thoughts. Working in pairs also reduces stress and embarrassment. If they give a wrong answer, for example, they won't feel shy because the embarrassment is shared. According to Andrews and Hull, learning is more effective when it takes place in social environments that provide authentic social cues about how knowledge is to be applied. In this regard, they demonstrated that stories provide a tool to transfer knowledge in a social context.

One of the positive aspects of TPS is that it gives students time to think about 
the question or the problem which is important and of a great effect. Students feel more comfortable if they are given enough time to think and organize their thoughts before they start expressing themselves. It is better than responding directly. The more time they think about it, the fewer mistakes they make. In addition to that, it also gives the teacher the opportunity to check students' understanding and comprehension.

\subsection{Teaching Oral Communication Skills through TPS}

There are many different techniques that can be used to help learners develop their communicative skills. For example, speaking which is one of the interactive skills can be improved through the use of interactive strategies such as TPS. The main element of this strategy is peer interaction. Learners are encouraged to interact and listen to each other. The use of think-pair-share strategy leads to active engagement. In fact, it provides learners with opportunities to think, to listen, to share and to reflect on their ideas and their peers' ideas.

\subsection{The Procedures that Are Followed in TPS Are}

-The teacher asks a question or introduces a problem.

-Students are given enough time to think individually in order to answer the question or suggest solutions for the problem. The time that is given to students depends on the complexity of the question or the problem.

-Students are asked to work in pairs in order to discuss their answers with their peers. They are given enough time to listen to each other ideas and to discuss them.

-Students are asked to share their ideas with the whole class. They are given the opportunity to share what they have discussed in pairs and to express themselves through speaking (Lyman, 1987).

\section{Research Problem}

To the researcher's long experience in teaching English for the Arabs, he noticed that most students find difficulty in communicating adequately and appropriately through speaking. This difficulty is due to lack of self-confidence, fear of making mistakes and fear of embarrassment. Considering these problems, the researcher applied TPS in an attempt to help students minimize these problems and thus improve oral communication skills.

\section{Objective of the Study}

Think-pair-share is one of the interactive strategies that can be used in speaking lessons to solve students' problems in communicating through eliminating the obstacles that hinder appropriate oral interaction. The skillful application of this strategy can help in making students more confident and able to speak and share ideas with their classmates in an enjoyable learning environment. This research is designed to measure the influence of think-pair-share on improving students of "English for Workplace" speaking skills at English Language Center/An-Najah 
National University in Nablus.

\section{Significance of the Study}

Since speaking is a very important skill and part of learning a foreign language, it is very necessary to analyze speaking difficulties which are encountered by EFL learners and to provide suitable solutions and effective strategies to solve them. In this study, the researcher investigated the difficulties and tried to solve them through the use of think-pair-share strategy. The results showed that this strategy has an effective influence on the learning process. It could be used as a feedback or a reference for teachers in planning an effective strategy to improve students' speaking skill. In fact, this study opened doors for both teachers and researchers to draw attention to think-pair-share strategy and its application in EFL speaking classes.

\section{Definition of Terms}

The following terms have the following meanings:

-ELC: It is at An-Najah National University in Nablus and it is the place where the English compulsory courses tests are held. Different English courses on different levels are taught there.

-EFL: It is a term used in teaching English for nonnative speakers.

-Think-pair-share: is a strategy that is used for teaching speaking. It includes three phases: thinking phase (individual work), discussing phase (pair work) and sharing phase (group work). Lyman (1987: p. 35) As for Kagan, Think-PairShare (TPS) is a collaborative learning strategy in which students work together to solve a problem or answer a question about an assigned reading.

\section{Literature Review}

For the sake of systematicity, organization and clarity, the researcher arranged literature review topically. Several researchers and scholars conducted research on think-pair-share strategy and its effect on the improvement of students' speaking skill. Lyman (1981) created the technique of think-pair-share. He described it as a pedagogical practice and cooperative procedure. Lyman's technique gives individual students time to think about a question or a problem given by the teacher, time to discuss the question or the solutions with a partner and time to share ideas with the class. It allows a great deal of interaction and communication among students. Moreover, it plays an important role in developing students' thinking and cognitive skills.

Schwab (1999) also explained the four steps of think-pair-share technique which are:

1) The teacher poses a question that provokes students and encourages them to think.

2) Students think individually about the given question.

3) Students share their ideas with their partners. 
4) Students share these ideas with the whole class.

To Pimm (1987) TPS proved to help learners in organizing the ideas they have when working in a cooperative environment. It also helps them to retain these ideas when sharing them with their classmates. As for Pressley (1992), he emphasized what Pimm previously stated. By giving learners enough time and opportunities to elaborate the ideas they have through discussion and sharing enhances the learning process and turns it to fun.

While Cobb (1991) disagreed with Pimm 1987 as he claimed that students gain more responsibility toward their own learning when they start to share what they have with others. They will depend more on themselves rather than on their teacher. With regard to students' background, that is, the first phase of TPS, Edge (1993) noted that knowing enough vocabulary in L2 is very important in creating an interaction among students. It supports successful discussion and communication.

In the area of keeping students involved in the class activities which emphasized the importance of TPA, Kagan in Kinzie et al. said that the strategy of think-pair-share was designed to keep students involved and engaged in class. They are required to listen to the teacher question and instruction, to think, to discuss, to respond and to share ideas with their classmates. In such a case, all students have an opportunity to learn by reflection and by verbalization.

In regard to the suitable learning environment where cooperative learning which is rich in authentic materials dominates, Arends (2008), Parker (2009) and Brady \& Tsay (2010) stated that cooperative learning requires students to engage in group activities which increase learning outcomes and interaction among students. In this respect, they overvalue the second phase of TPS. In this regard, applying TPS in the teaching practices can be a second phase of effective teaching and active learning as well (Raba \& Harzallah, 2015).

An idea which blends skillfully the three phases of TPS was shown clearly by Lyman (1987). He explained that TPS provides students with "food of thought" on a given topics to formulate individual opinions with their pairs and share the ideas with other students. Think Pair and Share is a simple model of cooperative learning. This is a technique that gives the opportunity for students to work independently an in collaboration with others, and it advantages to invite students participation.

\section{Research Questions}

The researcher hoped that this study will give answers to these questions:

1) What is the influence of "think-pair-share" strategy on improving the students of "English for workplace" oral communicative skills?

2) What is the role of gender in the influence of "think-pair-share" strategy in improving the students of "English for workplace" oral communicative skills?

3) What is the role of students' academic level in the influence of "think-pairshare" in improving the students of "English for workplace" oral communicative skills? 
4) What is the role of the students' specialization in the in the influence of "think-pair-share" in improving the students of "English for workplace" oral communicative skills?

\section{Methodology}

This descriptive study aimed to find out if the think-pair-share strategy can improve EFL students' oral communication skills as perceived by "English for Workplace" students of the English language center at An-Najah National University in Nablus during the first semester of the academic year 2015. To achieve this goal, the researcher used two qualitative tools to collect data. The two tools were semi-structured interviews for EFL teachers who taught "English for Workplace" at the ELC An-Najah National University and classroom observations of "English for Workplace" classes at ELC at An-Najah National University. The first tool contains six questions that require the interviewees' responses to the researcher's strategy; every interview lasted for almost two contact hours is the time given for two consequent lectures. The second tool that was used to collect data was classroom observations. This was conducted in February and March 2015. The observation continued for 8 weeks. The researcher applied the strategy of think-pair-share in "English for Workplace" classes in ELC in AnNajah National University-Nablus. He observed students' interaction with new strategy and their progress during the 8 weeks of the study.

\section{Results of the Study}

The first section reports the findings of the first tool which is the interview that was held with 10 EFL teachers about the use and validity of think-pair-share theory. The second section, on the other hand, reported the findings of the classroom observations of "English for Workplace" classes in the ELC at AnNajah National University in February and March 2015 (Table 1).

\section{Results of the Interview}

The interview was with 10 EFL teachers who work at ELC An-Najah National University. Interviewees spoke freely about the issue in English language. Their answers and opinions were as follows:

Table 1. Distribution of the study sample according to the variables of gender, academic level and qualification.

\begin{tabular}{|c|c|c|c|}
\hline Variable & Class & Frequency & Percentage \\
\hline \multirow{2}{*}{ Gender } & Male & 4 & 40.0 \\
\hline & Female & 6 & 60.0 \\
\hline \multirow{2}{*}{ Academic level } & $\mathrm{PhD}$ & 2 & 20.0 \\
\hline & Master & 8 & 80.0 \\
\hline \multirow{2}{*}{ Specialization } & TEFL & 6 & 60.0 \\
\hline & Language and literature & 4 & 40.0 \\
\hline & Total & 10 & 100.0 \\
\hline
\end{tabular}


Question 1. Have you ever tried think-pair-share in your speaking classes? All the interviewees said that they have tried this strategy in their speaking classes.

Question 2. Was the use of this strategy really effective in speaking classes? Interviewee 1 said that she found it very effective. Her students liked this idea. They like working together. They feel more engaged and secure because she's not focusing on each one of them individually, because sometimes they feel threatened or less confident when they work by their own. She emphasized that group work and peer work help to overcome communication problems. It's also fun. Students learn better in a funny way. They learn from each other and help each other. Interview 3 also agreed with interviewee one and said that it gave them more confidence to speak up what they have come up with through pair work. That was the only benefit that he have noticed because most of the time they do not cooperate with each other in such work. Interviewees 4, 5 and 6 all agreed that think-pair-share is really effective. They reported that their students participate more when working in pairs or groups. On the other hand, interviewee 2 explained that her students do not really work in pairs. They prefer to work by themselves. She keeps telling them that they should talk to one another and they should divide tasks but they rarely respond to her. She feels disappointed.

Question 3. How was your students' reaction? All interviewees said that their students enjoyed it especially because it allows interaction except for interviewee 2 who claimed that his students didn't enjoy it. He explained that maybe the reason behind this is that they did not use team work at school. Or maybe it is part of their culture and the way they were raised... "You should be the best" their parents keep saying.

Question 4. Do you organize their work and give them clear instructions and enough time to think and pair? Interviewees 1, 4, 5, 6 said that they give students enough time and I instruct them in English and Arabic. Interviewee 2 also reported that she gives them enough time to think and discuss in pairs but she instructs them only in English. Interview 3 explained that he it depends on the exercise. He gives them more time if the task or the question is a little bit complicated.

Question 5. Do you usually mix good students with weak ones? All interviewees reported that they mix weak students with good ones. So they can get benefited from each other.

Interviewee 2 explained that she doesn't mix them. They work with people sitting next to them. She claimed that they usually start complaining about changing places.

Question 6. When it comes to speaking do they speak a big deal? Interviewees 1, 4, 5 and 6 agreed that their students speak more when using think-pair-share strategy. They related this to the encouragement they get from each other. Interviewee 3 stated that not all students speak. He said the dominant students speak more than others.

Interviewee 2 claimed that her students don't speak much. For more emphasis, Table 2 shows the results: 
Table 2. Distribution of the results of the study sample on the study questions.

\begin{tabular}{cccc}
\hline Questions & Answer & Frequency $\%$ \\
\hline $\begin{array}{c}\text { Have you ever tried think-pair-share in your speaking } \\
\text { classes? }\end{array}$ & Yes & 10 & 100.0 \\
Classes? & No & 0 & 0.0 \\
Was the use of this strategy really effective in speaking & Yes & 9 & 90.0 \\
How was your students' reaction? & No & 1 & 10.0 \\
& students enjoyed it & 9 & 90.0 \\
Do you organize their work; give those clear & students didn't enjoy it & 1 & 10.0 \\
instructions and enough time to think and pair? & Yes & 10 & 100.0 \\
& No & 0 & 0.0 \\
Do you usually mix good students with weak ones? & Yes & 10 & 100.0 \\
& No & 0 & 0.0 \\
When it comes to speaking do they speak a big deal? & Not all of them speak & 1 & 10.0 \\
& They don't speak & 5 & 50.0 \\
& & 10 & 100.0 \\
\hline
\end{tabular}

\section{Results related to the second tool (observations):}

Classroom observation was the second tool that the researcher used. The observation which continued for 8 weeks during the first semester of the academic year 2015 was for students who were enrolled in "English for Workplace" at ELC An-Najah National University. The results were as follows:

\section{1st and 2nd weeks:}

During these weeks, the researcher noticed that some students didn't show cooperation. They were shy. He reported that they found it embarrassing to work in pairs with students from the last stage of the think-pair-share strategy. They also committed a lot of grammar mistakes in speaking. Some of them didn't speak at all; they just listened to their classmates.

\section{3rd and 4th weeks:}

During these weeks, the researcher noticed that students started to show some progress. They started to get on well with each other. They looked engaged in discussions and they seemed to be more comfortable. The tension that the researcher noticed during the first two weeks among pairs started somehow to disappear. They were enjoying their time. Among the indicators are the following utterances mentioned by some of the students: "This strategy increases our interaction and keeps us involved", "It helps us increase our oral achievement" and "It helps us reflect on our ideas". On the other hand, a few students refused to speak. They looked so embarrassed and not confident enough to participate.

\section{5th and 6th weeks:}

During these weeks the researcher reported that students were better engaged in the class interaction. Class participation was more than accepted; they become more willing and more read to share ideas. They improved a lot and committed less grammar mistakes in speaking and became more fluent in expressing themselves. Among the indicators are the following students' utterances: "we more motivated and more interested", "we are more self-confident than before", and 
"we are more responsible for our learning than before".

\section{7th and 8th weeks:}

During the last two weeks of the time of the study, students started to show noticeable progress. They were all engaged in thinking, discussing and sharing. During these weeks, they consumed less time in thinking. It seemed that they started to manage their ideas more effectively. All of them spoke and were confident while speaking. Students seemed to be motivated and happy in expressing themselves. One big indicator of motivation and willingness to speak were these phrases that they kept repeating "we didn't feel time", "we looked forward to meeting next", "we started to think creatively" and "we began to collaborate appropriately". For more illustration, Table 3 shows the progress.

\section{Discussion of Results}

Based on the findings related to the basic question: Can think-pair-share strategy improve EFL students' oral communication skills? In regard to the effectiveness of think-pair-share in improving students' oral communication skills, the findings of the study were the following:

The highest percentage of teachers agrees on the effectiveness of think-pairshare strategy in speaking classes. They found out that this strategy is really effective in engaging students. After the application of the strategy in speaking classes, students became more cooperative. They enjoyed working and interacting in the last two weeks. They started to show progress in speaking. They became more fluent. Moreover, it increases students' self-confidence. Students who were shy in the early stages started to speak and express themselves in later stages. In addition, students consumed less time in thinking afterwards because they started to learn how to organize their ideas. Students also seemed to enjoy learning in later stages. The learning process enhanced because students became more active and more enthusiastic and they started to interact through speaking. In fact, speaking achievements improved. In the last week, all students in the

Table 3. Distribution of the results of the study sample on the observation.

\begin{tabular}{|c|c|}
\hline $\begin{array}{c}\text { Duration of the } \\
\text { observation }\end{array}$ & Things observed; students' behavior \\
\hline 1 st and 2 nd weeks & $\begin{array}{l}\text { No cooperation, shyness and embarrassment. } \\
\text { A lot of grammatical errors in speaking. }\end{array}$ \\
\hline 3 rd and 4 th weeks & $\begin{array}{l}\text { Engagement in the discussions, feeling comfortable, enjoyment, more } \\
\text { interaction with some embarrassment. } \\
\text { Increasing the oral achievement, but not confidant enough. }\end{array}$ \\
\hline 5 th and 6 th weeks & $\begin{array}{l}\text { Better engagement and interaction, more fluent in expressing themselves, more } \\
\text { motivated and more interested and more self-confident. } \\
\text { fewer grammar mistakes in speaking. }\end{array}$ \\
\hline 7 th and 8 th weeks & $\begin{array}{l}\text { Engagement in thinking, discussing and sharing, consuming less time in } \\
\text { thinking, managing their ideas more effectively, more motivation and } \\
\text { willingness to speak. } \\
\text { Progressing in speaking, better cooperation. }\end{array}$ \\
\hline
\end{tabular}


class spoke. Shy students became sociable and less stressed while working in pairs, or in groups and chorus if storytelling technique is adopted by teachers and students (Tanni \& Raba, 2015).

The above mentioned results agree with what Lyman (1981), Edge (1993), Kagan in Kinzie et al. and Parker (2009) in their studies conducted on think-pair-share strategy. They all found out that think-pair-share increases interaction among students. It has a social dimension since it increases cooperation and communication among them. Moreover, the results support what Brady \& Tsay (2010) said about academic achievements. It found out that the strategy improved students' achievements in speaking.

As well, the study emphasizes what Pressley (1992) stated about the enhancement of learning process. It also agrees with what Pimm (1987) said about the effectiveness of think-pair-share in helping students organizing their ideas before discussing them. On the other hand, the findings of the study emphasized what Cobb (1991) stated about the importance of think-pair-share in increasing students' self-confidence and responsibility toward their own learning. In fact, both the interview and classroom observations proved the positive effects of think-pair-share in improving students' speaking skill. It is important to underlie that researcher noticed some differences between males' and females' responses in favor of the academic level; almost similar differences in the students' responses were noticed between different specializations in favor of students in the scientific faculties. Moreover, the researcher did not notice differences in the students' responses due to gender.

\section{Conclusion}

In conclusion, using Think-pair-share strategy in EFL classrooms has helped both teachers and learners in many different ways. In fact, it has a positive impact on both of them. Regarding students, TPS application in the classroom has helped them think and organize their thoughts. As a result, they have started to manage their own learning and to gain a sense of responsibility. Moreover, they have shown readiness to speak in the target language with more confidence and fluency. These activities have also motivated learners so they have gained a positive attitude toward speaking in a foreign language. Students have begun to have opportunities so they can show how good they are in speaking and sharing ideas. Whenever students have opportunities they will show their creativity. As a result, we will produce balanced individuals who have the ability to function in their cultures and able to solve problems. Regarding teachers, they became more aware of the importance of TPS strategy in improving students' oral skills. This strategy promotes interaction among students. In fact, it creates an enjoyable learning environment and increases motivation among learners. Students became more cooperative and able to communicate successfully.

\section{Recommendations}

Based on the conclusion of the research, it is recommended that: 
1) Teachers of English language need to use think-pair-share strategy in their speaking classes since it helps to improve their achievements and increases cooperation and motivation.

2) Curriculum designers need to increase the activities that use the thinkpair-share technique since it helps to develop the critical thinking skills.

3) Students should be encouraged to apply the think-pair-share technique in speaking lessons to develop their oral communication skills and to be more selfassured.

4) Other related studies should be conducted to develop more effective strategies for improving speaking skill.

\section{References}

Arends, R. I. (2008). Learning to Teach: Belajar untuk Mengajar. Buku Dua. (Penterjemah: Helly Prayitno Soetjipto dan Sri Mulyantini Soetjipto). Yogyakarta: Pustaka Pelajar.

Bailey, K. M. (2005). Practical English Language Teaching: Speaking. New York: McGrawHill. Faculty of Arts, 2004. Undergraduate Catalog. Nakhon Pathom: Silpakorn University Press.

Brady, M., \& Tsay, M. (2010). A Case Study of Cooperative Learning and Communication Pedagogy: Does Working in Teams Make a Difference? Journal of the Scholarship of Teaching and Learning, 10, 78-89.

Chaney, A. L., \& Burk, T. L. (1998). Teaching Oral Communication in Grades K-8. Boston: Allyn and Bacon.

Cobb, P. et al. (1991). Assessment of a Problem-Centered Second-Grade Mathematics Project. Journal for Research in Mathematics Education, 22, 3-29. https://doi.org/10.2307/749551

Edge, J. (1993). Essentials of English Language Teaching. Longman: New York.

Goh, C. (2007). Teaching Speaking in the Language Classroom. Singapore City: SEAMEO Regional Language Centre.

Lyman, F. (1981). The Responsive Classroom Discussion. In A. S. Anderson (Ed.), Mainstreaming Digest (pp. 109-113). College Park, MD: University of Maryland College of Education.

Lyman, F. (1987). Think-Pair-Share: An Ending Teaching Technique. MAA-CIE Cooperative News, 1, 1-2.

Millis, B. J. (2012). IDEA Paper No. 53: Active Learning Strategies in Face-to-Face Courses: The IDEA Center.

http://www.ideaedu.org/Portals/0/Uploads/Documents/IDEA\%20Papers/IDEA\%20Pa pers/PaperIDEA 53.pdf

Nunan, D. (2006). Task-Based Language Teaching in the Asia Context: Defining “Task”. Asian EFL Journal, 8, 12-18.

http://www.asian-efl-journal.com/September_2006 EBook editions.pdf

Parker, C. (Eds.) (2009). Foundational Methods: Understanding Teaching and Learning. Toronto: Pearson Education.

Patil, Z. N. (2008). Rethinking the Objectives of Teaching English in Asia. Asian EFL Journal, 10, 227-240.

http://asian-efl-journal.com/1015/quarterly-journal/2008/12/rethinking-the-objectivesof-teaching-english-in-asia/ 
Pimm, D. (1987). Speaking Mathematically: Communication in Mathematics Classrooms. New York: Routledge \& Kegan Paul.

Raba, A. A. A. M., \& Harzallah, H. T. M. (2015). Effective Teaching from An-Najah National University M.A. Students' Perspectives. Journal of Languages and Culture, 6, 52-60. https://doi.org/10.5897/JLC2015.0325

Schwab, J. H., Gunter, M. A., \& Estes, T. H. (1999). Instruction: A Models Approach (3rd ed.). Boston, MA: Allyn \& Bacon.

Tanni, Z. A. I., \& Raba, A. A. A. M. (2015). Storytelling as an Aid in Promoting Oral Proficiency of Grade Eleven Students from Teachers' Perspectives in Tulkarm District. US-China Foreign Language, 13, 710-722.

Trent, J. (2009). Enhancing Oral Participation across the Curriculum: Some Lessons from the EAP Classroom. Asian EFL Journal, 11, 256-270.

http://repository.lib.eduhk.hk/jspui/handle/2260.2/6061

Zhang, Y. (2009). Reading to Speak: Integrating Oral Communication Skills. English Teaching Forum, 47, 32-34. http://files.eric.ed.gov/fulltext/EJ923446.pdf

Submit or recommend next manuscript to SCIRP and we will provide best service for you:

Accepting pre-submission inquiries through Email, Facebook, LinkedIn, Twitter, etc. A wide selection of journals (inclusive of 9 subjects, more than 200 journals)

Providing 24-hour high-quality service

User-friendly online submission system

Fair and swift peer-review system

Efficient typesetting and proofreading procedure

Display of the result of downloads and visits, as well as the number of cited articles

Maximum dissemination of your research work

Submit your manuscript at: http://papersubmission.scirp.org/

Or contact ce@scirp.org 